\title{
Corporate Social Responsibility in the Rule of Law and Welfare State Concept
}

\author{
Busyra Azheri \\ Faculty of Law Andalas University \\ Jl. Universitas Andalas, Limau Manis, Padang, West Sumatera 25129, Indonesia \\ Tel./Fax:+62-751-27066E-mail: ba1969bd@gmail.com
}

Submitted: Jun 16, 2016; Reviewed: Jul 22, 2016; Accepted: Jul 29, 2016

\begin{abstract}
The provision of the Law Number 40 of 2007 concerning Limited Company on Corporate Social Responsibility has changed the nature of such responsibility from voluntary into mandatory. Similarly, it strengthened welfare state (verzorgings staat) concept as commanded by Article 33 (3) and (4) of the 1945 Constitution of the Republic of Indonesia. Denaturing of this Corporate Social Responsibility is progressively assured by the Decision of Indonesian Constitutional Court, so that responsibility must be performed as legal responsibility or mandatory.
\end{abstract}

Keywords: Corporate Social Responsibility; Limited Company; Welfare State DOI: http://dx.doi.org/10.20956/halrev.v1n2.313

\section{INTRODUCTION}

After the Corporate Social Responsibility (CSR) became a trending issue through the promulgation of the Law Number 40 of 2007 concerning Limited Company (Limited Company Act) as the substitution of Law Number 1 of 1995, the issue since then provoked pros and cons even resistance from various quarters on the provision of Article 74, Section (1), (2) and (3) of the Limited Company Act on CSR. Article 74 says as follows:

(1) Company that runs its business in and/ or related to natural resources is mandated to perform Social and Environmental Responsibility.
(2) Such Social and Environmental Responsibility as aimed by Section (1) is a Company' obligation that is budgeted and accounted for as Company' expense and its implementation is conducted by considering fit and proper aspects.

(3) Companies that fail to meet the mandate as mentioned in Section (1) shall be subjected to sanctions according to the provisions of the law.

(4) Further provisions on Social and Environmental Responsibility shall be regulated by Governmental Regulation.

The peak of the discourse leads to judicial review of the provisions of Article 74 of the Limited Company Act to the Consti- 
tutional Court, represented by Indonesian Chamber of Commerce and Industry (Kamar Dagang dan Industri Indonesia, KADIN), Central Executive Body of Young Entrepreneurs Association of Indonesia, (Badan Pengurus Pusat Himpunan Pengusaha Muda Indonesia, BPP HIPMI), Chair of Indonesian Women Entrepreneur Association (Ikatan Wanita Pengusaha Indonesia, IWAPI), PT. Lili Panma, PT. Apac Centra Centertex, Tbk, and PT. Kreasi Tiga Pilar. The petition was registered as No. 53/PUU-VI/2008, whereas the petition is referred to the provisions of Article 28D Section (1), Article 28-I Section (2) and Article 33 Section (4) of the 1945 Constitution.

The Constitutional Court' Decision ruled that the provision of Article 74 Section (1), (2) and (3) of the Limited Corporation Act is not in contrast to the provisions in the Constitution as referred to by the petitioners. Hence, the provision of Article 74 is no longer debatable. The issue after the Constitutional Court' Decision was how to create awareness among actors of business to implement CSR principles in their businesses as part of the state' attempt to achieve welfare for its people as mandated by Article 33 of the 1945 Constitution that complies with welfare state principles (verzorgings staat).

The argument is inseparable from the understanding on the concept of CSR itself. This is confirmed by results of various researches and surveys that indicate that the understanding and implementation of CSR among Indonesian businesses is very poor. ${ }^{1}$

Survey result of KOMPAS on August 7, 2007 edition indicated less than $30 \%$ of Indonesian companies implement CSR. Implementation among the $30 \%$ are
By far, the businesses view CSR as a voluntary activity; philanthropy and charity and thus, CSR should not have been regulated in an Act. The poor understanding to the CSR is proven by the impact of a company' existence.

Theoretically, the existence of a company should at least show some effects, i.e. absorption of manpower, increase in economic productivity, and may pose as asset of development in the national or regional level. Yet in reality, for years, the existence of a company in an area tends to "marginalize" people in the surroundings, even to a more extreme level, play role in planting the seeds of latent conflicts. This condition is affirmed by the government, as proven in Medium-term National Development Plan (Rencana Pembangunan Jangka Menengah Nasional, RPJMN) of 2004-2009. The plan describes issues related to and agenda on development, that there had been negative impacts of development; welfare gaps between groups of society, on incomes, and gaps on inter-regional development, etc.

Other empirical facts indicate that social dynamics are changing rapidly and followed by the lack of government roles in development whereas the roles of the private sector in development is increasing. ${ }^{2}$ Such condition is triggered by the improvement on the awareness and demand of the society on the social justice, environmental issues, and human rights as well as law enforcement pertaining to the law enforcement. In other

only in the form of donations related to natural disasters. Teguh. (2006). Corporate Social Responsibility Must be Performed. Paper in seminar "Corporate Social Responsibility: Integrating Social Aspects into The Business", Association of Management Students, University of Gajah Mada (UGM), Yogyakarta, 11 March 2006. 
words, transparency in 'will informed' is required by the existence of a company in the contemporary condition.

Similarly, from the economic aspect of a company, so far most companies are still holding on to the classic economic theory of "profit maximization" as once stated by Adam Smith "the primary goal of a company is to suppress cost to the lowest possible and to improve efficiency to the highest possible for the maximization of profit". However, in the contemporary global and free market era, this doctrine is obsolete and a newer paradigm is required; how a company in its activities is able to create "positive image" for the stakeholders; by means of implementing principles of CSR in the world of business.

On the other hand, CSR has been a demand, proven by the establishment of global economic binds such as the WTO, AFTA, APEC, EU. Those economic binds require their member states to be able to comply with various requirements for competition and to be able to enter a certain region, such as the requirement for ISO 14000 and 14001 that are related to environmental management, and ISO $2600^{3}$ on the guidelines of implementation and application of CSR.

The issue nowadays is that there has not been a similar view on both the philosopicaltheoretical level, and the practical level on what CSR is. ${ }^{4}$ Such absence on the view on CSR affects companies and stakeholders to make their own variables on comprehending and implementing CSR. It is not entirely

\footnotetext{
ISO 26000 was launched in October 2008. The ISO is voluntary and contains only guidelines on CSR standards. For further information, refer to www.mvoplatform.nl; accessed on October 282007.

4 Sonny Keraf. (1998). Etika Bisnis, Tuntutan dan Relevansinya. Yogyakarta: Kanisius, p. 113.
}

wrong that at the time of the promulgation of the Limited Company Act on July 20 2007, pros and cons, and resistance emerged towards the provisions of CSR in Article 74 of the Act. Under the circumstances, this writing attempts to provide an understanding towards the essentials of CSR as an attempt to prosperous people, based on the welfare state doctrine.

\section{ANALYSIS AND DISCUSSION \\ Corporate Social Responsibility: The Shape of a History}

Up to present, there has been no similar view on the meaning of CSR. The Business comprehend CSR as necessary in the sustainability of business and their stakeholders, yet at best, only a small minority of businesses implement CSR. This is in line with the statement of Gurvy Kavei that the CSR practices is believed to be the fundamental basis for sustainable development, not only for companies but also for the stakeholders in the broadest sense. ${ }^{5}$

For a better understanding on the definition or formulation of CSR, the Author will explain as follows:

a. The World Business Council for Sustainable Development

The organization mentions CSR as a "continuing commitment by business to behave ethically and contribute to economic development while improving the quality of life of the workforce and their families as well as of the local community and society at large".

\footnotetext{
Teguh. (2006). Op.Cit.
} 
b. World Bank

The World Bank iterated CSR as "the commitment of business to contribute to sustainable economic development working with employees and their representatives, the local community and society at large to improve quality of life, in ways that are both good for business and good for development"

\section{c. European Union}

EU formulated that "CSR is a concept whereby companies integrate social and environmental concerns in their business operations and in their interaction with their stakeholders on a voluntary basis".

d. Article 1 Point 3 of Law No. 40 of 2007 concerning Limited Company

Social and Environmental Responsibility is the commitment of a Company to partake in the sustainable economic development for the sake of improving the qualities of beneficial life and environment, both to the Company itself and the society at large.

In principle, the formulations of CSR by WBCSD and World Bank are both emphasizing CSR as the Business commitment to contribute in the sustainable economic development, in cooperation with company' employees, family of the employees, and local residents in improving the quality of life. However, World Bank added as long as such activities are helpful to the company and development itself. Meanwhile, the definition by EU only depicts CSR as a concept where companies attempt to integrate social and environmental aspects with the stakehold- $\mathrm{ers}^{6}$ on the basis of 'voluntary' in conducting their businesses. The formulation of CSR in the Limited Company Act attempts to separate between social responsibility with the environmental responsibility. Yet, such separation is still describing company' commitment in the sustainable economic development in the course of improving the quality and envronment of life.

Such distinction is strengthened by the formulation made by Trinidad and Tobacco Bureau of Standard (TTBS) which concludes that CSR is related to the balues and standards performed in relations to the operation of a company. Hence, CSR is defined as an ethical commitent in business, lawful operation and contribution to the improvement of economy as well as the improvement of the quality of life of the employees and their families, the local community, and society at large. ${ }^{7}$

In regards to that, reinterpretation is necessary on the understanding of the principles of CSR by companies comprehensively. If by far CSR is identicized as responsibility in an an sich social meaning, then in the future, the word 'responsibility' must be comprehended as "legal responsibility". ${ }^{8}$ In doing so, then the sense of CSR from "voluntary" can be turned into "mandatory". When CSR is understood as an obligation of a company, then the implementation of CSR

\footnotetext{
Sony Keraf divides stakeholder into 2, i.e. Primary group, consisting capital or shares owners, creditors, employees, suppliers, consumers, distributors and competitors or partners; Secondary group, consisting local government, social groups, media, support group, society in general, and local community. Read further in Sonny Keraf. (1998). Op.Cit., p. 90.

Rasyid Idris. "Corporate Social Responsibility: Sebuah Gagasan dan Implementasi” Fajar Online, Makasar, 12 September 2006.

B Busyra Azheri. "Menggugat Social Responsibility Perusahaan". Padang Ekspres Daily, Wednesday, 28 March 2007.
} 
will be advantageous to the shareholders and stakeholders for it will create mutualistic relations. Consequently, companies should view CSR not only as ethical-moral burden, but in fact as an obligation to be accounted for as aimed by the provisions in Articles 74 Section 2 of the Limited Company Act.

\section{Welfare State (Verzorgings Staat)}

Theoretically, the state occupation on natural resources is based on the sovereignty (souvereniteit) theory. ${ }^{9}$ Such notion is inseparable from the statement of van Vollenhoven; the state as the highest organization of the nation is given the power to rule everything, and the state, based on its position, is in possession to create rules or law. ${ }^{10}$

On the other hand, JJ. Rousseau states that state power as an institution resulted from "Social Contract" aimed at protecting collective, private, and individual power. ${ }^{11}$ However, it must be comprehended that, what individuals release or provide to the state, are some of their powers, not their sovereignty. Therefore, state power is not unlimited power (postestas legibus omnibus soluta), as there are several legal provisions that binds the state power, such as the law of the nature and the law of the divine (leges naturae et devinae) as well as a more general laws that applies to all nations which is

9 Theory on State Power is based on 3 theories: Theocracy, Power, and Juridical Theories. According to Thomas Hobbes, John Locke, and JJ. Rousseau, the Juridical Theory in its development is divided into 3: Patrimonial, Patriarchal, and Convention Theories. Read more in Abrar Saleng. (2004). Hukum Pertambangan. Yogyakarta: UII Press, p. 7.

10 Notonagoro. (1984). Politik Hukum dan Pembangunan Agraria di Indonesia. Jakarta: Bina Aksara, p. 99.

11 J.J. Von Schmid. (1958). The Great Minds on State and Law. Translation by R. Wiratno, D. Dt. Singomangkuto, and Djamadi. Jakarta: Pembangunan, p. 176. called "leges imperii". ${ }^{12}$ According to Yudha B. Ardhiwisastra, ${ }^{13}$ legas imperii is the constitution of a state that contains provisions on which power goes to whom and limits of its exercises.

In line with the aforementioned Sovereignty and the Social Contract Theories, theoretically the state power on natural resources comes from the people, which is called the nation' rights. The state is viewed as territoriale publieke rechtsgemeenschap van overheid en onderdanen (public territory of legal community of the government and the subjects). ${ }^{14}$ On such basis the state is authorized to regulate the occupation, management, and use of all mining potentials on its territory internally. Related to the configuration of law on occupation and management of natural resources that was once applied in Indonesia, two principles emerge; i.e. "Domein Verklaring"15 and the State Occupying Rights (Hak Menguasai Negara, HMN) as confirmed by Article 33 Section (3) of the 1945 Constitution; "The land, the waters and the natural resources within shall be under the powers of the State and shall be used to the greatest benefit of the people". The essence of Article 33 Point (3) of the 1945 Constitution as formulated

12 Abrar Saleng. (2004). Op.Cit., p. 8.

13 Yudha B. Ardhiwisastra. (1999). Imunitas Kedaulatan Negara di Forum Pengadilan Asing. Bandung: Alumni, p. 30.

14 Ronald Z. Titahelu. (1993). Penetapan Asas-asas Hukum Umum dalam Penggunaan Tanah untuk Sebesar-besar Kemakmuran Rakyat. (Dissertation). Surabaya: Graduate School of Airlangga University, p. 141.

15 Domein Verklaring Principle; visible in Article 1 of Agraris Besluit of 1870, which, in its basic principles states that "all lands unless otherwise proven of its ownership rights are State property (domain)". Domein Verklaring Principle was implemented by the Netherlands-India government in attempting to provide opportunity for investors to invest... primarily for plantation... in the territory of Netherlands-India. This policy affected the shift of land ownership; from custombased ownership into state domain. 
by Indonesian founding fathers has led Indonesia into a welfare state (verzorgings staat).

Welfare State Theory is a combination of the concept on Rule of Law (rechtsstaat) and welfare state. According to Bagir Manan, Rule-of-Law-Welfare State is a concept where the state or government acts not only as security guard for the social order, but as the patron for implementing social justice, public welfare, and the greatest benefit of the people. ${ }^{16}$ The birth of Rule-of-Law-Welfare State was a reaction towards the liberal and the socialistic rule-of-law states. Both rulesof-law are in possession of distinct ideology, reflected on the difference of the concept of occupation on economic resources as explained in later part of this writing.

Mohammad Hatta ${ }^{17}$ as one of the actors in the formulation of the 1945 Constitution, before formulating Article 33, made a sythesis on an economic system which he called "cooperative socialism system". The system is based on 3 core pillars, i.e.: First, visions of western socialism that is based on humanity with implementation of democracy on politics; Second, islamic teachings that is based on the principles of justice and fraternity, and high valuation to individual human being as God' creation; Third, mutual cooperation (gotong royong) as hereditary value of Indonesia. ${ }^{18}$ The three pillars were then formulated into Article 33 of the 1945 Constitution as the basis of

16 Bagir Manan. (1996). Politik Perundang-undangan dalam Rangka Mengantisipasi Liberalisasi Perekonomian. Scientific Speech, Faculty of Law of Lampung University, Bandar Lampung, p.16, in Abrar Saleng, Op.Cit., p. 9.

17 Mohammad Hatta. (1983). Kumpulan Pidato II. Jakarta: Inti Idayu Press, p. 157.

18 Ibidem
Indonesian economic system which is based on welfare state principle.

According to Mac Iver, the sociocapitalist state concept or new liberalism that emphasizes welfare function is no longer viewing the state merely as instrument of power, but as agent of service, applied in the form of welfare state with the following characteristics: ${ }^{19}$

(1) In a welfare state, people' socioeconomic rights are most important;

(2) Considerations on efficiency is more important than politically-oriented distribution of power, and thus, the roles of the executives are greater than that of the the legislatives;

(3) The ownership rights is not absolute;

(4) The state is not merely as guardian of order and security, or in other words, night watch officer (nachtwakerstaat), but it also participates in social and economic efforts;

(5) There are more theorems of administration law are that rule socialeconomic realm and provide certain burdens to citizens;

(6) The roles of public law tend to heave private law, consequently, the roles of the state is broader;

(7) The rule-of-law is more matteroriented that emphasizes a more matter-oriented social justice.

The rule-of-law state with the aforementied concepts place the state roles in a strong and broad sense in the attempt to create public welfare and social justice. Experts may refer to this kind of state concept by various terms, among others, 'social service state' or an agency of service, social rule-of law state, (sociale rechtsstaat), a state that runs public welfare (bestuurszorg),

19 Akbar Saleng. Op. Cit., p. 14. 
and welfare state (verzorgingstaat). ${ }^{20}$

Based on the legal theories on states as proposed by Enteveres, that the state power is legal power, consequently, the validity of power is determined by law. ${ }^{21}$ When the law ends, so does the power possessed by the state. Law and power are in one unity. Related to the notion, Usep Ranawijaya confirmed that state is an organization with the highest power for the Indonesian people, obtaining its power from: ${ }^{22}$

(1) People' sovereignty, the application of state power is based on the bestowal of power from the people, as stated by Article 1 Point (2) of the 1945 Constitution;

(2) Legal sovereignty, appoint the law as the basis of state power and law is sourced from society awareness as stated the the Elucidation of the 1945 Constitution;

(3) State sovereignty, appoint the state as a self-power source, since state is the highes form of life unity.

Meanwhile, another expert, Sjachran Basah states that state power in Indonesia is derived from "integrated duet" harmoniously; from the people's sovereignty theorem and legal sovereignty that both deliver a ruleof-law state based on Pancasila. ${ }^{23}$ Therefore, Pancasila is the source of legal order that functions as state ideology (rechtsidee) and state fundamental norm (staatsfundamentalnorm).

$20 \quad$ Ibid, p.14.

21 Padmo Wahjono. (1984). Masalah Ketatanegaraan Indonesia Dewasa Ini. Jakarta:, Ghalia Indonesia, p. 157. Compare with Abrar Saleng. Op. Cit., p. 44.

22 Usep Ranawijaya. (1983). Hukum Tata Negara Indonesia, Dasar-dasarnya. Jakarta: Ghalia Indonesia, p. 183.

23 Sjachran Basah. (1986). Perlindungan Hukum Terhadap Sikap Tindak Administrasi Negara. Scientific Oration at the 24th Anniversary of Padjadjaran University, Bandung, p. 2.
Related to Pancasila as state ideology, Larenz proposed that legal ideology serves a constitutive function that provides meaning to law and functions to limit, in a sense, what cannot be united with it is not law. ${ }^{24}$ Then Radbuch expresses the function of legal ideology is as the constitutive basis of legal formation, in a sense that without legal ideology all norms of law shall loose its meaning as law, and at the same time, as negative regulatory parameter to assess fairness or unfairness a positive law.

The Elucidation of the 1945 Constitution in part of the governance system, it is expressed that "Indonesia is a state based on the rule of law (rechtsstaat), not based on power (machtstaat)". Upon detailed assessment, this entails that the provision is a repudiation towards absolutism of power, a denial to all kinds of oppression of human rights in the Pancasila democratic state. Yet, it must be comprehended that the rule-of-law state aimed by the Elucidation of the 1945 Constitution is not in a rule-of-law state in formal sense or night watch agent (nachtwakerstaat), but a rule-of-law state in matter sense, or welfare state (verzorgingsstaat) and the theorem of economic social democracy or modern rule-of-law state. ${ }^{25}$

Upon viewing from the welfare state concept, the state is nor merely the guardian of security and order of the society, but also as the main bearer of the responsibility to implement social justice, public welfare and the greatest welfare of the people. ${ }^{26}$ These

\footnotetext{
$24 \quad$ Abdul Kadir Besar. "Implementasi Cita Hukum dan Penerapan Asas-asas Hukum Nasional Sejak Lahirnya Orde Baru". Majalah Hukum Nasional, Special Edition No. 1 \& 2 1995, BPHN, Jakarta, p. 27.

25 Bagir Manan. Politics of....., Op. Cit., pp. 15-16.

26 Ibid, pp. 19-20.
} 
are visible in the Elucidation of the 1945 Constitution, elaborated in several Articles as follows:

(1) Article 27 Point (2): "Each national shall be entitled to proper occupation and livelihood for humanity."

(2) Article 33 Point (3): "Soil and water and natural wealth contained therein shall be controlled by the state and used for the welfare of the people to the utmost."

(3) Article 34 Point (1): "The indigent and abandoned children shall be raised by the state".

Hence, it can be concluded that elements in the dimensions of welfare state are basically referred to the form of welfare state. Further for Indonesians, this is not only as concept for establishing nation and state, but it is a legal ideology, and state ideology.

Referring to the concept of modern rule-of-law state, the state/the government is not only required to refer its actions to law, but it is also given broad roles, duties and responsibilities to provide prosperity for its people. On such consideration, Bagir Manan $^{27}$ expresses that moder ruleof-law state must contain three aspects: 1) Political aspect that compels limitation of state; 2) Legal aspect that emphasizes legal supremacy, legality principles and the rule of law; and 3) Social-economic aspect that emphasizes social justice and public welfare.

The three aspects take its start at human rights and social-economic welfare. Meanwhile in classical concept of rule-oflaw state, human rights are only emphasized in political rights, hence this concept is not

\footnotetext{
27 Bagir Manan. (1994). Hubungan antara Pusat dan Daerah Menurut UUD 1945. Jakarta: Pustaka Sinar Harapan, p. 38.
}

convincing. Consequently, the concept of human rights needs to be broadened into social perspective, i.e. social human rights (sociale grondrechten or sociale mensenrechten). On the base of this social human rights, the state/government is provided authorities, duties, and responsibilities to partake in the livelihood of individuals or society. Such understanding delivers the theorem of economic democracy or popularization in economic sector.

However, in modern rule-of-law state, this social human rights are related to socialeconomic aspect. Akbar Saleng says that the essence of social-economic aspecy is about social justice and people' welfare. ${ }^{28}$ Meanwhile according to Bagir Manan, social justice must include all dimensions of social life in a nation and state. Yet, admittedly economic justice is a key factor in all kinds of state and government duties to implement public welfare and the greatest prosperity of the people. ${ }^{29}$

In particular relations to economic justice and state occupying rights on natural resources, it takes the creation and management of economic ministration that takes side with the people. The creation and management of such system is performed through reinstatement and implementation of various basic, existing aspects, either philosophical, ideological, or constitutional. According to W. Friedmann, the management of economic system that takes side with the people is inseparable from the function of state in

\footnotetext{
28 Abrar Saleng. Op.Cit.

29 Maret Priyanta. (2015). "Pembaruan dan Harmonisasi Peraturan Perundangundangan Bidang Lingkungan dan Penataan Ruang Menuju Pembangunan Berkelanjutan". Hasanuddin Law Review, 1(3), 337-349.
} 
economy, i.e..$^{30}$

a. State as provider of people's welfare;

b. State of regulator regulator;

c. State as entrepreneur or run certain sectors through state-owned-corpora tions; and

d. State as umpire to formulate fair standard on the performance of economic sector, including state corporations.

If CSR is viewed in modern welfare state perspective, then the principles of CSR is highly relevant with social human rights, particularly related to the aspect of social justice in economy. In other words, the study on CSR is essentially related to the issues on social justice and prosperity for all citizens. Consequently, the state occupation on natural resources that is based on Article 33 Point (3) and (4) of the 1945 Constitution must be able to provide social justice and welfare for all the citizens of Indonesia.

Considering Article 33 Point (3) of the 1945 Constitution as the constitutional basis for the state occupation on natural resources, then the provision must be used as fundamental law and the highest law and its Point (4) as an operational basis. As constitutional basis, its substance implicates on how efforts or management and use of natural resources would serve people' welfare objective. Consequently, the state must be able to:

(1) Regulate and manage the allotment and use of ownership object;

(2) Determine and regulate the legal relations between individuals and the object of ownership;

30 W. Friedmann. (1971). The State and The Rule of Law in A Mixed Economy. London: Stevens and Sons, p. 3, as cited in Abrar Saleng, Loc.Cit.
(3) Determine and regulate the relations between individuals and the legal acts on object of ownership.

Based on such grounds, then Article 33 point (3) and (4) of the 1945 Constitution was formulated in a way that the meaning of the word "state occupation" is implemented in State Occupying Rights that is in line with prosperity as the objective of State Occupying Rights on the principles of economic democracy. In legal perspectives, the meaning of "for the greatest benefit of the people" is a legal assurance on people' social and economic rights, so they may live properly as citizens. On such grounds, then it was a mistake if the CSR provision as stated in Article 74 of the Limited Company Act is viewed in contrast to Articles 28D point (1), 28I point (2) 33 point (4) of the 1945 Constitution.

The Constitutional Court's Verdict that denies the legal standing lawsuit on the provision of CSR contained in Article 74 of the Limited Company Act strengthens the concept of welfare state (verzorgings staat) as implemented as part of State Occupying Rights. The Constitutional Court Verdict also describes state intervention so CSR that had so far been considered as voluntary transformed into mandatory. The shift in the nature of CSR is state intervention in order to improve its people's welfare. However, it must be duly noted that state intervention is not to be overdone as it would trigger other issues such as "inefficiency". Consequently, further regulations on CSR is necessary as a completion of welfare state.

This regulation must describe mutualistic symbiosis wherein the relations 
between the social and business interests and legal duties become three inseparable things. When the issued regulation does not accommodate this, then companies would evade from CSR when the regulation on CSR creates injustice. Companies must comply with and be obedient to legal regulations as law is formulated as instruction or state policy. No equivalence between the commanded and the commanding (compliance principle). Companies must cooperate with the state in the attempt to make the people prosperous (cooperation principle).

Considering the provisions on CSR as welfare state' policy, CSR becomes collective responsibilities of the state, business actors, companies, and the society. It should not create repudiation from companies to find loopholes on the legal regulations for further exploitation for the sake of evading such responsibility. CSR is affirmative regulation, which according to the argumentation of the natural law (lex naturalis), that requires not only compliance but also cooperation from all stakeholders.

CSR as affirmative regulation in the context of welfare state requires cooperation among the state, society, and companies, especially those that are in or related to natural resources cultivation. Hence, investors both domestic and foreign that act as exclusive entities that are isolated and alienated from surrounding society should create harmonious, good cooperation with the surrounding society so it would provide the greatest benefit for the society. This is in line with the principle of pareto superiority, where companies in running their activities do not sacrifice others' interests. Similarly, companies need to be more aware that the sustainability of the companies depend on the relations of the companies with the society and surroundings of the company. This is in line with the legitimacy principle that companies are bound to contract with the society to run their activities based on the values of justice. Disharmony between the value system of company and the society' value system may lead to a condition where companies lose their legitimacy, and thus, this condition may pose a threat to the sustainability of the companies themselves.

\section{CONCLUSION}

CSR as regulated in the provision of Article 74 of the Limited Company Act is an implementation of the provision in Article 33 point (3) and (4) of the 1945 Constitution of the Republic of Indonesia must be comprehended as commitment of companies to improve the welfare of the surrounding societies where companies run their activities Such commitment is no longer understood as voluntary, but a commitment that is mandatory in nature. With the shift of the nature of CSR, then the responsibility concept should self-evidently be comprehended as legal responsibility. As legal responsibility, then companies that is absent in implementing CSR would receive sanction.

The shift in the nature of CSR from voluntary into mandatory is already in line with the concept of welfare state as aimed by Article 33 point (3) and (4) of the 1945 Constitution. Consequently, the state must attempt in its strongest manner to optimize the use of natural resources in Indonesia 
shall be able to improve its people's welfare. The responsibility to create welfare for the people is not merely the responsibility of the state, but also of the business and of the society itself, so companies, in running their activities would not sacrifice any other stakeholders. This is in line with legitimacy principle wher companies are bound to contract with the society to run their activities based on the values of justice. This would also mean that the Constitutional Court's Verdict that denies the judicial review on Article 74 of the Limited Company Act that was assumed in contrast to Articles 28D point (1), 28I point (2) and 33 point (4) of the 1945 Constitution is already in line with the concept of welfare state (verzorgings staat).

\section{BIBLIOGRAPHY}

Abdul Kadir Besar. "Implementasi Cita Hukum dan Penerapan Asas-asas Hukum Nasional Sejak Lahirnya Orde Baru". Majalah Hukum Nasional, Special Edition No. 1 \& 2 1995. Jakarta: BPHN.

Abrar Saleng. (2004). Hukum Pertambangan. Yogyakarta: UII Press.

Bagir Manan. (1994). Hubungan antara Pusat dan Daerah Menurut UUD 1945. Jakarta: Pustaka Sinar Harapan.

Bagir Manan. (1996). Politik Perundang-undangan dalam Rangka Mengantisipasi Liberalisasi Perekonomian. Scientific Speech, Faculty of Law of Lampung University, Bandar Lampung.

Busyra Azheri. "Menggugat Social Responsibility Perusahaan". Padang Ekspres Daily, Wednesday, 28 March 2007.
J. J. Von Schmid. The Great Minds on State and Law. Translated by: R. Wiratno, D. Dt. Singomangkuto, and Djamadi. (1962). Ahli-ahli Pemikir Besar tentang Negara dan Hukum. Jakarta: Pembangunan.

Kompas News. August 7, 2007 edition.

Maret Priyanta. (2015). "Pembaruan dan Harmonisasi Peraturan Perundangundangan Bidang Lingkungan dan Penataan Ruang Menuju Pembangunan Berkelanjutan". Hasanuddin Law Review, 1(3), 337-349. doi: http://dx.doi. org/10.20956/halrev.v1n3.113.

Mohammad Hatta. (1983). Kumpulan Pidato II. Jakarta: Inti Idayu Press.

Notonagoro. (1984). Politik Hukum dan Pembangunan Agraria di Indonesia. Jakarta: Bina Aksara.

Padmo Wahjono. (1984). Masalah Ketatanegaraan Indonesia Dewasa Ini. Jakarta:, Ghalia Indonesia.

Rasyid Idris. "Corporate Social Responsibility: Sebuah Gagasan dan Implementasi" Fajar Online, Makasar, 12 September 2006.

Ronald Z. Titahelu. (1993). Penetapan Asasasas Hukum Umum dalam Penggunaan Tanah untuk Sebesar-besar Kemakmuran Rakyat. (Dissertation). Surabaya: Graduate School of Airlangga University.

Sjachran Basah. (1986). Perlindungan Hukum Terhadap Sikap Tindak Administrasi Negara. Scientific Oration at the 24th Anniversary of Padjadjaran University, Bandung.

Sonny Keraf. (1998). Etika Bisnis, Tuntutan dan Relevansinya. Yogyakarta: Pener- 
bit Kanisius.

Teguh. (2006). Corporate Social Responsibility Must be Performed. Paper in seminar "Corporate Social Responsibility: Integrating Social Aspects into The Business", Association of Management Students, University of Gajah
Mada, Yogyakarta, 11 March 2006.

Usep Ranawijaya. (1983). Hukum Tata Negara Indonesia, Dasar-dasarnya. Jakarta: Ghalia Indonesia.

Yudha B. Ardhiwisastra. (1999). Imunitas Kedaulatan Negara di Forum Pengadilan Asing. Bandung: Alumni. 